\title{
Postępowanie z nadciśnieniem tętniczym w ostrym uszkodzeniu nerek
}

\section{Hypertension management in acute kidney injury}

\author{
Marta Soltysiak, Krystyna Widecka \\ Klinika Hipertensjologii i Chorób Wewnętrznych Pomorskiego Uniwersytetu Medycznego w Szczecinie
}

\begin{abstract}
Summary
Despite the fact that in recent years the concept of hypertension treatment has been verified and the management in special situations and groups of patients has been standardized, there are not many reports of antihypertensive therapy in patients with acute kidney injury.

Acute renal failure, defined as a sudden decline of kidney function, is a clinical syndrome of various etiologies, often accompanies by hypertension, and specific pathological mechanism determines the therapeutic management. Diuretics are first-line drugs, particularly preferred in patients with volume overload. RAA blockers are not recommended for the hypertension treatment in acute kidney injury, but the broad definition of AKI forces individualization of therapy in various clinical situations - the results of large clinical trials show the benefits of ACE inhibitors in cases of HTA associated with acute glomerulopathies or vasculitis.

Prevalence of drugs that affect potassium levels contribute to the rising incidence of hyperkalemia, which can be a consequence of both - acute and chronic kidney diseases. In case of a dynamically growing levels of potassium in AKI there is a need to decrease the dose or withdrawal of RAA blockers and mineralocorticoid antagonists.
\end{abstract}

key words: AKI, acute renal failure, hypertension

Arterial Hypertens. 2015, vol. 19, no. 4, pages: 203-206

DOI: $10.5603 / A H .2015 .0026$

\begin{abstract}
Wstęp
Ostatnie lata były wyjątkowe pod względem liczby opublikowanych wytycznych postępowania w nadciśnieniu tętniczym. W 2013 roku ukazały się wytyczne European Society of Hypertension i European Society of Cardiology (ESH/ESC) oraz stanowisko American Heart Association, American College of Cardiology $i$ Centers for Disease Control and Prevention (AHA) $A C C / C D C$ ), a w 2014 roku wytyczne American Society of Hypertension i International Society of Hypertension (ASH/ISH) i wytyczne ekspertów amerykańskich Joint National Committee (JNC8) [1-4].

Adres do korespondencji: lek. Marta Sołtysiak

Klinika Hipertensjologii i Chorób Wewnętrznych SPSK 1 PUM

ul. Unii Lubelskiej 1, 71-252 Szczecin

tel.: (091) 4253 550, faks: (091) 4253552

e-mail: marta.soltysiak00@gmail.com
\end{abstract}

Ponadto, w bieżącym roku ukazały się długo oczekiwane wytyczne rodzimego, Polskiego Towarzystwa Nadciśnienia Tętniczego (PTNT) [5]. Mimo że w ostatnich latach koncepcja leczenia nadciśnienia tętniczego uległa weryfikacji, a postępowanie w szczególnych sytuacjach i grupach pacjentów standaryzacji, to aktualna literatura medyczna nie poświęca wiele miejsca terapii hipotensyjnej u pacjentów z ostrym uszkodzeniem nerek.

Ostre uszkodzenie nerek (AKI, acute kidney injury), zwykle określane jako nagły spadek funkcji nerek, stanowi zespół kliniczny o różnej etiologii [6].

V M Copyright $@ 2015$ Via Medica, ISSN 2449-6170 
W ostatniej dekadzie kilkukrotnie redefiniowano pojęcie AKI, rozszerzając je o całe spektrum stanów przebiegających z ostrą niewydolnością nerek [7-10]. Potencjalnych przyczyn wystąpienia AKI można upatrywać w pierwotnych i wtórnych, nefrologicznych jednostkach nozologicznych, takich jak ostre śródmiąższowe zapalenie nerek, ostre kłębuszkowe zapalenie nerek, nefropatia obturacyjna, zwyrodnienie wielotorbielowate nerek, a także w przebiegu zatruć, niedokrwienia czy układowych chorób naczyń, przebiegających z zajęciem nerek [6]. Nawet łagodna i potencjalnie odwracalna postać AKI niesie za sobą szereg klinicznych konsekwencji, w tym zwiększone ryzyko zgonu [11-14]. Nadciśnienie tętnicze nierzadko współistnieje z ostrymi chorobami nerek i tylko właściwe postępowanie diagnostyczno-terapeutyczne zwiększa potencjał opieki medycznej i poprawia rokowanie u chorych z AKI $[15,16]$.

\section{Terapia hipotensyjna w ostrym uszkodzeniu nerek}

W dotychczasowych doniesieniach niewiele wiadomo na temat związku nadciśnienia tętniczego z ostrą dysfunkcją nerek. Do ostrej reakcji nadciśnieniowej w przebiegu AKI dochodzi najczęściej z powodu wzmożonej aktywacji układu renina-angiotensyna-aldosteron (RAA) w odpowiedzi na hipoperfuzję i niedokrwienie w obrębie mikrokrążenia nerek [13]. Lekami pierwszego rzutu w terapii nadciśnienia tętniczego w przebiegu AKI są diuretyki pętlowe [5]. Diuretyki są grupą leków szczególnie preferowaną u pacjentów z objętościowym przeciążeniem płynami, ułatwiającą kontrolę równowagi płynów w organizmie [6]. Przydatność diuretyków w celu poprawy wyników leczenia u pacjentów z AKI nie jest jednoznaczna $-z$ jednej strony leki te mogą wykazywać działanie nefroprotekcyjne, hamować dynamiczny rozwój AKI, przyspieszać proces powrotu prawidłowej funkcji nerek, z drugiej zaś mogą obniżać perfuzję przez nerki, przyczyniając się do powstania przednerkowej niewydolności nerek [6].

Zgodnie z wytycznymi PTNT w terapii hipotensyjnej u pacjentów z AKI należy unikać leków z grupy inhibitorów konwertazy angiotensyny oraz sartanów [5].

Zaburzenia czynności nerek, które towarzyszą leczeniu przeciwnadciśnieniowemu są często wynikiem obniżenia ciśnienia tętniczego, istotnie częściej obserwowanego przy zastosowaniu inhibitorów konwertazy angiotensyny lub sartanów (ACEI lub ARB), co można wiązać $\mathrm{z}$ dodatkowym potencjałem tych leków do wazodylatacji naczyń krążenia kłębuszko- wego [14]. Ponadto ACEI przyspieszają spadek filtracji kłębuszkowej poprzez hamowanie angiotensynozależnej konstrykcji tętniczki odprowadzającej [14]. A zatem w przypadkach przebiegających ze zmniejszoną objętością wewnątrznaczyniową właściwym postępowaniem jest czasowe odstawienie ACEI, ARB i ewentualna kontynuacja leczenia dopiero po przywróceniu równowagi płynowej.

Szerokie spektrum chorób skrywanych pod pojęciem AKI determinuje konieczność indywidualizacji terapii oraz każdorazowej oceny zasadności wskazówek terapeutycznych dla konkretnej sytuacji klinicznej.

Nadciśnienie tętnicze u pacjentów z ostrymi glomerulopatiami, takimi jak poststreptococcowe kłębuszkowe zapalenie nerek, prawdopodobnie spowodowane jest retencją sodu i wody, co znajduje potwierdzenie w supresji układu RAA i zwiększeniu uwalniania przedsionkowego peptydu natriuretycznego [17]. Wyniki badań przeprowadzonych u pacjentów $\mathrm{z}$ zespołem nerczycowym i ostrym kłębuszkowym zapaleniem nerek sugerują, że zatrzymywanie sodu towarzyszące tym zaburzeniom jest wynikiem zwiększonej resorpcji w cewkach zbiorczych [18]. Zjawisko to thumaczy się względną opornością na przedsionkowy peptyd natriuretyczny w następstwie szybszego rozkładu cyklicznego monofosforanu guanozyny (cGMP) przez fosfodiesterazę oraz zwiększoną aktywnością pompy sodowo-potasowej w kanalikach zbiorczych części korowej nefronu [19, 20]. Choć występowanie nadciśnienia tętniczego wzrasta wraz ze stadium zaawansowania glomerulopatii, to opisywane są również przypadki choroby nadciśnieniowej u pacjentów z prawidłowym stężeniem kreatyniny w surowicy [19]. Preferowaną grupą leków w terapii nadciśnienia tętniczego u pacjentów z ostrą chorobą kłębuszków nerkowych są diuretyki pętlowe. W przypadkach opornych na wstępne leczenie moczopędne dane z piśmiennictwa wykazują skuteczność ACEI [21].

Nadciśnienie tętnicze jest również powszechne w ostrych chorobach naczyniowych, takich jak zapalenie naczyń czy twardzina, w których elewacja ciśnienia wynika z mechanizmu niedokrwiennego, a nie — jak opisywano wyżej — przeciążenia płynami [22]. Ta różnica w patomechanizmie kłębuszkowego i naczyniopochodnego AKI może mieć znaczenie terapeutyczne [22]. W etiologii nadciśnienia tętniczego związanego z ostrym naczyniopochodnym uszkodzeniem nerek podkreśla się indukowaną niedokrwieniem aktywację układu RAA — tłumaczy to potencjalne korzyści z zastosowania ACEI u tych chorych [23]. Mocne dane z piśmiennictwa potwierdzają też skuteczność ACEI w leczeniu nadciśnienia tętniczego u pacjentów z AKI w przebiegu guzkowego zapalenia tętnic [24]. 
Osobnym zagadnieniem związanym $\mathrm{z}$ terapią przeciwnadciśnieniową jest hiperkaliemia, wikłająca tak ostrą, jak i przewlekłą chorobę nerek [25]. Hiperkaliemia staje się zjawiskiem coraz bardziej powszechnym z powodu rosnącej populacji pacjentów z chorobami sercowo-naczyniowymi, przewlekłą chorobą nerek, stosującymi leki, które modulują wydalanie potasu przez wpływ na układ RAA lub receptory mineralokortykoidowe [14, 26]. Pilność postępowania w hiperpotasemii $\mathrm{w}$ przebiegu AKI związana jest z ryzykiem nagłego zatrzymania krążenia i obejmuje nie tylko redukcję lub odstawienie preparatów hipotensyjnych interferujących $\mathrm{z}$ nerkową sekrecją potasu, ale także odpowiednią płynoterapię, leczenie moczopędne czy rozważenie wskazań do dializoterapii [26].

\section{Streszczenie}

Mimo że w ostatnich latach koncepcja leczenia nadciśnienia tętniczego uległa weryfikacji, a postępowanie w szczególnych sytuacjach i grupach pacjentów standaryzacji, to aktualna literatura medyczna nie poświęca wiele miejsca terapii hipotensyjnej u pacjentów z ostrym uszkodzeniem nerek (AKI).

Ostre uszkodzenie nerek, definiowane jako nagły spadek funkcji nerek, stanowi zespół kliniczny o różnej etiologii, któremu nierzadko towarzyszy nadciśnienie tętnicze, a określony patomechanizm determinuje postępowanie terapeutyczne. Diuretyki są lekami pierwszego rzutu, szczególnie preferowanymi u pacjentów z objętościowym przeciążeniem płynami. Co prawda w aktualnych wytycznych PTNT nie zaleca się leków z grupy antagonistów RAA w leczeniu nadciśnienia tętniczego w przebiegu ostrego uszkodzenia nerek, ale szeroka definicja AKI wymusza konieczność indywidualizacji terapii w różnych sytuacjach klinicznych — wyniki dużych badań klinicznych wykazują bowiem korzyści ze stosowania inhibitorów konwertazy angiotensyny w przypadkach HTA związanego z ostrymi glomerulopatiami czy układowymi zapaleniami naczyń.

Rozpowszechnienie terapii lekami modulującymi stężenie potasu przyczynia się do coraz częstszego występowania hiperkaliemii, będącej następstwem tak ostrej, jak i przewlekłej choroby nerek. Postępowanie w przypadku dynamicznie narastającego stężenia potasu w AKI obejmuje redukcję lub odstawienie leków z grupy antagonistów RAA i antagonistów mineralokortykoidowych.

słowa kluczowe: AKI, ostre uszkodzenie nerek, nadciśnienie tętnicze

Arterial Hypertens. 2015, vol. 19, no. 4, pages: 203-206

DOI: $10.5603 / A H .2015 .0026$

\section{Piśmiennictwo}

1. Mancia G., Fagard R., Narkiewicz K. i wsp. 2013 ESH/ESC Guidelines for the management of arterial hypertension: the Task Force for the management of arterial hypertension of the European Society of Hypertension (ESH) and of the European Society of Cardiology (ESC). J. Hypertens. 2013; 31: 1281-1357.

2. Go A.S., Bauman M., Coleman King S.M. i wsp. AHA/ACC/CDC Science Advisory: an effective approach to high blood pressure control: a science advisory from the American Heart Association, the American College of Cardiology, and the Centers for Disease Control and Prevention. J. Am. Coll. Cardiol. 2013; doi: 10.1016/j. jacc.2013.11.007.

3. Weber M.A., Schiffrin E.L., White W.B. i wsp. Clinical practice guidelines for the management of hypertension in the community: a statement by the American Society of Hypertension and the International Society of Hypertension. J. Clin. Hypertens. 2014; 16: 14-26.

4. James P.A., Oparil S., Carter B.L. i wsp. 2014 Evidence-based guideline for the management of high blood pressure in adults: report from the Panel Members Appointed to the Eighth Joint National Committee (JNC 8). JAMA 2014; 311: 507-520.

5. Tykarski A., Narkiewicz K., Gaciong Z. i wsp. Guidelines for the Management of Hypertension. Arterial Hypertens. 2015; 2: 53-83.

6. KDIGO Clinical Practice Guideline for Acute Kidney Injury. Kidney International Supplements 2012: 2; doi:10.1038/kisup.2012.2.

7. Mehta R.L., Pascual M.T., Soroko S. i wsp. Spectrum of acute renal failure in the intensive care unit: the PICARD experience. Kidney Int. 2004; 66: 1613-1621.
8. Waikar S.S., Curhan G.C., Wald R. i wsp. Declining mortality in patients with acute renal failure, 1988 to 2002. J. Am. Soc. Nephrol. 2006; 17: 1143-1150.

9. Uchino S., Kellum J.A., Bellomo R. i wsp. Acute renal failure in critically ill patients: a multinational, multicenter study. JAMA 2005; 294: 813-818.

10. Liangos O., Wald R., O’Bell J.W. i wsp. Epidemiology and outcomes of acute renal failure in hospitalized patients: a national survey. Clin. J. Am. Soc. Nephrol. 2006; 1: 43-51.

11. Libório A.B., Leite T.T., De Oliveira Neves F.M. i wsp. AKI complications in critically ill patients: Association with mortality rates and RRT. CJASN 2015; 10: 21-28.

12. Lafrance J.P., Miller D.R. Acute kidney injury associates with increased long-term mortality. J. Am. Soc. Nephrol. 2010; 21: 345-352.

13. Posadas M.A., Yang V., Ho B. i wsp. Acute renal failure and severe hypertension from a page kidney post-transplant biopsy. Scientific World Journal 2010; 10: 1539-1542.

14. Palmer B.F. Renal dysfunction complicating the treatment of hypertension. N. Engl. J. Med. 2002; 16: 1256-1261.

15. Mehta R.L., Kellum J.A., Shah S.V. i wsp. Acute Kidney Injury Network: report of an initiative to improve outcomes in acute Sidney injury. Critical Care 2007; 11: 1-8.

16. Bakris G.L., Ritz E. The message for World Kidney Day 2009: hypertension and kidney disease: a marriage that should be prevented. Kidney Int. 2009; 75: 449.

17. Rodríguez-Iturbe B., Colic D., Parra G. i wsp. Atrial natriuretic factor in the acute nephritic and nephrotic syndromes. Kidney Int. 1990; 38: 512 . 
18. Buerkert J., Martin D.R., Trigg D. i wsp. Sodium handling by deep nephrons and the terminal collecting duct in glomerulonephritis. Kidney Int. 1991; 39: 850.

19. Valentin J.P., Qiu C., Muldowney W.P. i wsp. Cellular basis for blunted volume expansion natriuresis in experimental nephrotic syndrome. J. Clin. Invest. 1992; 90: 1302.

20. Zolty E., Ibnou-Zekri N., Izui S. i wsp. Glomerulonephritis and sodium retention: enhancement of $\mathrm{Na}+\mathrm{K}+$-ATPase activity in the collecting duct is shared by rats with puromycin induced nephrotic syndrome and mice with spontaneous lupus-like glomerulonephritis. Nephrol. Dial. Transplant. 1999; 14: 2192.

21. Parra G., Rodríguez-Iturbe B., Colina-Chourio J. i wsp. Short-term treatment with captopril in hypertension due to acute glomerulonephritis. Clin. Nephrol. 1988; 29: 58.
22. Catapano F., Chiodini P., De Nicola L. i wsp. Antiproteinuric response to dual blockade of the renin-angiotensin system in primary glomerulonephritis: meta-analysis and metaregression. Am. J. Kidney Dis. 2008; 52: 475.

23. Traub Y.M., Shapiro A.P., Rodnan G.P. i wsp. Hypertension and renal failure (scleroderma renal crisis) in progressive systemic sclerosis. Review of a 25-year experience with 68 cases. Medicine 1983; 62: 335-352.

24. Merkel P.A. Treatment and prognosis of polyarteritis nodosa. UpToDate, Waltham, MA. (Accessed on November 2015).

25. Lehnhardt A., KemperM.J. Pathogenesis, diagnosis and management of hiperkalemia. Pediatr. Nephrol. 2011; $26: 377-384$.

26. McCullough P.A., Beaver T.M., Bennett-Guerrero E. Acute and chronic cardiovascular effects of hyperkalemia: new insights into prevention and clinical management. Rev. Cardiovasc. Med. 2014; 15: 11-23. 